\title{
ONEIDA UTOPIA
}





\section{ONEIDA UTOPIA}

A COMMUNITY SEARCHING FOR HUMAN
HAPPINESS AND PROSPERITY

ANTHONY WONDERLEY 


\section{Copyright (C) 2017 by Cornell University}

All rights reserved. Except for brief quotations in a review, this book, or parts thereof, must not be reproduced in any form without permission in writing from the publisher. For information, address Cornell University Press, Sage House, 512 East State Street, Ithaca, New York 14850.

First published 2017 by Cornell University Press

Printed in the United States of America

\section{Library of Congress Cataloging-in-Publication Data}

Names: Wonderley, Anthony Wayne, 1949- author.

Title: Oneida utopia : a community searching for human happiness and prosperity / Anthony Wonderley.

Description: Ithaca : Cornell University Press, 2017. Includes bibliographical references and index.

Identifiers: LCCN 2017025823 (print) | LCCN 2017027517 (ebook) | ISBN 9781501709807 (pdf) | ISBN 9781501712449 (epub/mobi) | ISBN 9781501702709 (cloth : alk. paper)

Subjects: LCSH: Oneida Community-History. | Noyes, John Humphrey, 1811-1886. | Collective settlementsNew York (State)—History-19th century. | Utopian socialism - New York (State) - History-19th century.

Classification: LCC HX656.O5 (ebook) | LCC HX656.O5 W59 2017 (print) | DDC 307.7709747/64-dc23

LC record available at https:/ / lccn.loc.gov/2017025823

Cornell University Press strives to use environmentally responsible suppliers and materials to the fullest extent possible in the publishing of its books. Such materials include vegetable-based, low-VOC inks and acid-free papers that are recycled, totally chlorine-free, or partly composed of nonwood fibers. For further information, visit our website at cornellpress.cornell.edu.

Figure 1 is from the author's collection. All other images are from the Oneida Community Mansion House, used by permission.

Cover illustration: Bible communists of Oneida gather for a bee to hoe and rake, 1867. Photo courtesy of the Oneida Community Mansion House. 
To Patricia A. Hoffman 
